\title{
Natural chemotherapeutic alternatives for controlling of haemonchosis in sheep
}

\author{
Dominika Mravčáková', Zora Váradyová', Anna Kopčáková1, Klaudia Čobanová1, L'ubomíra Grešáková1, \\ Svetlana Kišidayová', Michal Babják², Michaela Urda Dolinská2, Emília Dvorožňáková2, Alžbeta Königová2, \\ Jaroslav Vadlejch³ ${ }^{3}$ Adam Cieslak ${ }^{4}$, Sylwester Ślusarczyk ${ }^{5}$ and Marián Várady $2^{2 *}$
}

\begin{abstract}
Background: Parallel in vitro and in vivo experiments were designed to evaluate promising chemotherapeutic alternatives for controlling haemonchosis in ruminants. In vitro anthelmintic activities (egg hatch test - EHT; larval development test - LDT) of aqueous and methanolic herbal extracts Mix1 and Mix2 were investigated. The in vivo effects of dietary supplementation with Mix 1 and Mix2 on the parasitological status, inflammatory response, antioxidant parameters and microbial community of the lambs infected experimentally with Haemonchus contortus were investigated. Lambs were divided into four groups for the in vivo study: uninfected control lambs (C), infected lambs (I), infected lambs supplemented with Mix1 (I + Mix 1$)$ and infected lambs supplemented with Mix2 (I + Mix2). The experimental period was 70 days.

Results: The number of eggs per gram (EPG) of feces was quantified 22, 30, 37, 44, 51, 58, 65 and 70 days post-infection, and mean abomasal worm counts were assessed 70 days post-infection. Quantitative analyses identified 57.3 and $22.2 \mathrm{mg} / \mathrm{g}$ phenolic acids, 41.5 and $29.5 \mathrm{mg} / \mathrm{g}$ flavonoids and 1.4 and $1.33 \mathrm{mg} / \mathrm{g}$ protoberberine-type alkaloids in Mix1 and Mix2, respectively. The methanolic extracts of the herbal mixtures in both in vitro tests had higher anthelmintic effects $(P<0.01)$ than the aqueous extracts, but the effects did not differ significantly between Mix1 and Mix2 $(P>0.05)$. I + Mix1 and I+ Mix2 lowered mean EPGs between 44 and $70 \mathrm{~d}$ by 58.1 and $51.6 \%$, respectively. The level of IgG antibodies against $\mathrm{H}$. contortus increased significantly after infection in each infected group.
\end{abstract}

Conclusion: These results represent the first monitoring of the in vitro anthelmintic effects of herbal mixtures on $\mathrm{H}$. contortus. The in vivo experiment indicated that the anthelmintic effect was not sufficient for the elimination of parasites, but this herbal treatment may affect the host over a longer term, reducing the parasitic infection in the host.

Keywords: 165 rRNA gene, Total antioxidant capacity, Haemonchus contortus antigen, Phytochemicals, UHRMS

\section{Background}

Modern production systems require the use of nutraceuticals for optimal production and health in ruminant nutrition. Gastrointestinal nematode (GIN) infections are the prevalent parasitic diseases contributing to the morbidity and mortality of various livestock species worldwide. Infection by the GIN Haemonchus contortus is mainly controlled by chemoprophylaxis by the repeated application of anthelmintics, which has led to

\footnotetext{
* Correspondence: varady@saske.sk

${ }^{2}$ Institute of Parasitology, Slovak Academy of Sciences, Hlinkova 3, 04001

Košice, Slovak Republic

Full list of author information is available at the end of the article
}

the increased risk of anthelmintic resistance and multidrug resistance $[1,2]$. Resistance to anthelmintics also applies to the novel anthelmintic monepantel $[3,4]$. Herbs with important biological activities are potential nutraceuticals for controlling GINs in ruminants [5-7]. A variety of herbs from traditional medicine with healthpromoting properties have been used to treat various diseases in both humans and animals for centuries [8]. Alternative control approaches can therefore involve combinations of traditional herbal medicines $[9,10]$, the pharmacologically active plant compounds [11, 12] and the self-medication of grazing animals [13, 14]. Polyphenols, especially tannins, flavonoids and phenylpropanoids,

(C) The Author(s). 2019 Open Access This article is distributed under the terms of the Creative Commons Attribution 4.0 International License (http://creativecommons.org/licenses/by/4.0/), which permits unrestricted use, distribution, and 
mainly have anthelmintic $[15,16]$ and antioxidative and anti-inflammatory [17, 18] properties. Hoste et al. [19] have demonstrated that the manipulation of host nutrition provides useful options for controlling GINs as a component of an integrated multidisciplinary strategy. The ability of the host to resist GIN infections also depends on the development of a protective acquired immune response [20]. Interactions between intestinal parasites, microbial communities and immune systems play a relevant role in modulating each other and in the maintenance of homeostasis [21].

Our previous trials found that the dry medicinal herbs can be used as chemotherapeutic alternatives for controlling of haemonchosis in ruminants based on their beneficial effect [22-24]. The bioactive phytochemicals responsible for anthelmintic, antioxidant and anti-inflammatory activities in various herbal mixtures have not yet been characterized in vitro. Our goal was therefore to examine (1) the in vitro anthelmintic activities of extracts from two dry mixtures of medicinal herbs against $H$. contortus, and (2) the in vivo impact of these mixtures on inflammatory, parasitological, antioxidant, mineral and microbial community parameters of lambs experimentally infected with $H$. contortus.

\section{Results}

\section{Bioactive compounds}

The herbal compositions (Table 1), fermentation parameters (Table 2) and bioactive compounds (Tables 3, 4) of Mix1 and Mix2 are presented. Quantitative analyses of Mix1 identified $57.3 \mathrm{mg} / \mathrm{g}$ phenolic acids (Nos. 1-9, 19, 21, 26 and 28) and $41.5 \mathrm{mg} / \mathrm{g}$ flavonoids (Nos. 10-18, 20, 22-25, 27 and 29-33) (Table 3). Quantitative analyses of Mix2 identified $22.2 \mathrm{mg} / \mathrm{g}$ phenolic acids (Nos. 1-6, 20, 23, 26 and 29) and $29.5 \mathrm{mg} / \mathrm{g}$ flavonoids (Nos. 7-19, 21, 22, 24, 25, 27, 28 and 30) (Table 4). Protoberberine-type alkaloids were also identified in Mix1 $(1.4 \mathrm{mg} / \mathrm{g})$ and Mix2 $(1.33 \mathrm{mg} / \mathrm{g})$ based on comparisons with chelidonine and protopine standards.

\section{EHT, LDT and parasitological status of lambs}

In vitro anthelmintic activity of the methanolic and aqueous herbal mixtures extracts are presented in Table 5. Both mixtures generally affected hatching and development within the range of the test concentrations. The Mix1 and Mix2 results did not differ significantly in either in vitro test. The methanolic extracts, however, had a significantly stronger effect than the aqueous extracts in both mixtures and tests. The patterns of egg shedding for I, I + Mix1 and I + Mix2 are shown in Fig. 1. Data from D44 were statistically compared and used to determine the reduction in egg output for I + Mix 1 and I + Mix2 relative to I. Mean fecal eggs per gram (EPGs) for all groups increased until D44. The EPGs in the lambs treated with Mix1 and Mix2 decreased from D44 until the end of the experiment. Eggs per gram for I similarly decreased, but only to D58 and then remained stable. The egg-output data indicated that mean EPG decreased between D44 and D70 for I + Mix1 and I+ Mix2, by 58.1 and $51.6 \%$, respectively. EPGs after D58 were always lower for I + Mix1 and I + Mix 2 than I. Eggs per gram on D70 was significantly lower for I + Mix 1 than I $(P<0.05)$. Mean body weights and live-weight gains did not differ significantly $(P>0.05)$ between the experimental groups. The necropsy on D70 found a significant decrease at abomasal worm count for I+ Mix1 compared to I (Table 5).

\section{Effect on inflammatory, antioxidant and mineral parameters}

Mean serum IgG concentrations were influenced by treatment and the treatment $\times$ time interaction $(P<0.001)$ and differed significantly $(P<0.01$ and 0.001 , respectively) for I vs. I + Mix1 by D22, D51 and D70 and for I vs. I + Mix2 by D22 (Table 6). Mean serum calprotectin concentrations were influenced by treatment, time and the treatment $\times$ time interaction $(P<0.001)$. Calprotectin concentrations for I + Mix 2 ranged from 1.833 to

Table 1 Compositions of the herbal mixtures

\begin{tabular}{|c|c|c|c|c|c|c|c|}
\hline \multicolumn{4}{|l|}{ Mix1 } & \multicolumn{4}{|l|}{ Mix2 } \\
\hline Species & Family & Part used & $\%$ in Mix1 & Species & Family & Part used & $\%$ in Mix2 \\
\hline Artemisia absinthium L. & Asteraceae & Stem & 1.0 & Artemisia absinthium L. & Asteraceae & Stem & 1.0 \\
\hline Matricaria chamomilla L. & Asteraceae & Flower & 13.4 & Achillea milefolium $\mathrm{L}$. & Asteraceae & Stem & 12.4 \\
\hline Foeniculum vulgare Mill. & Apiaceae & Seed & 5.0 & Calendula officinalis $\mathrm{L}$. & Asteraceae & Flower & 12.4 \\
\hline Fumaria officinalis L. & Papaveraceae & Stem & 13.4 & Matricaria chamomilla L. & Asteraceae & Flower & 12.4 \\
\hline Hyssopus officinalis L. & Lamiaceae & Stem & 13.4 & Cichorium intybus L. & Asteraceae & Stem & 12.4 \\
\hline Malva sylvestris $\mathrm{L}$. & Malvaceae & Flower & 13.4 & Fumaria officinalis L. & Papaveraceae & Flower & 12.4 \\
\hline Melissa officinalis L. & Lamiaceae & Stem & 13.4 & Hypericum perforatum L. & Hypericaceae & Stem & 12.4 \\
\hline Plantago lanceolata $\mathrm{L}$. & Plantaginaceae & Leaf & 13.4 & Malva sylvestris $\mathrm{L}$. & Malvaceae & Stem & 12.4 \\
\hline Solidago virgaurea $\mathrm{L}$. & Asteraceae & Stem & 13.4 & Urtica dioica $\mathrm{L}$. & Urticaceae & Stem & 12.4 \\
\hline
\end{tabular}

Medicinal herbs (AGROKARPATY, Plavnica, Slovak Republic and BYLINY Mikeš s.r.o., Číčenice, Czech Republic) 
Table 2 Fermentation parameters of the dietary substrates after $24 \mathrm{~h}$ of in vitro incubation

\begin{tabular}{|c|c|c|c|c|c|c|c|c|}
\hline \multirow[t]{2}{*}{ Parameter } & \multicolumn{4}{|c|}{ Rumen fluid inoculum } & \multicolumn{4}{|c|}{ Fresh fecal inoculum } \\
\hline & Mix 1 & Mix2 & $\mathrm{MH}$ & Concentrate & Mix 1 & Mix2 & $\mathrm{MH}$ & Concentrate \\
\hline $\mathrm{pH}$ & 6.86 & 7.04 & 7.16 & 6.92 & 7.28 & 7.32 & 7.41 & 7.13 \\
\hline $\mathrm{NH}_{3}-\mathrm{N}(\mathrm{mg} / \mathrm{L})$ & 130 & 147 & 122 & 126 & 158 & 218 & 167 & 127 \\
\hline Total gas (mL/g DM) & 180 & 178 & 120 & 222 & 91 & 90 & 61 & 140 \\
\hline $\mathrm{CH}_{4}(\mathrm{mmol})$ & 6.99 & 6.68 & 7.90 & 7.62 & 6.49 & 6.21 & 7.05 & 7.06 \\
\hline Total SCFA (mmol/L) & 48.3 & 47.8 & 42.4 & 53.4 & 46.8 & 47.2 & 43.1 & 49.3 \\
\hline Acetate (mol\%) & 60.0 & 60.3 & 69.1 & 63.4 & 66.3 & 65.9 & 66.1 & 67.2 \\
\hline Propionate (mol\%) & 16.4 & 16.4 & 17.2 & 19.1 & 20.1 & 20.9 & 20.2 & 23.7 \\
\hline Butyrate (mol\%) & 10.9 & 10.3 & 10.4 & 13.1 & 3.14 & 2.82 & 2.50 & 8.82 \\
\hline Total ciliate protozoa $\left(10^{3} / \mathrm{mL}\right)$ & 94 & 99 & 114 & 160 & - & - & - & - \\
\hline Entodinium spp. $\left(10^{3} / \mathrm{mL}\right)$ & 91 & 96 & 111 & 155 & - & - & - & - \\
\hline Epidinium spp. $\left(10^{3} / \mathrm{mL}\right)$ & 2.96 & 3.19 & 3.17 & 5.39 & - & - & - & - \\
\hline
\end{tabular}

Mix 1 herbal mixture 1, Mix2 herbal mixture 2, Concentrate commercial concentrate composed of barley, soybean meal, wheat bran, bicarbonate and mineral-vitamin premix, $M H$ meadow hay

$4.207 \mathrm{ng} / \mathrm{mL}$ and differed significantly for I vs. I + Mix2 by $\mathrm{D} 51$ and $\mathrm{D} 70(P<0.001$ and 0.01 , respectively).

Serum total antioxidant capacity (TAC), superoxide dismutase activity (SOD) and activity of blood glutathione peroxidase (GPx) (Table 7) were influenced by treatment $(P<0.001)$, and SOD and GPx activities were influenced by time $(P<0.05$ and 0.001 , respectively). Serum $\mathrm{Zn}$ concentration was influenced by treatment $(P<0.05)$ and time $(P<0.001)$ (Table 8$)$.

Serum Fe concentration was influenced by treatment $(P<0.001)$, time $(P<0.001)$ and the treatment $\times$ time interaction $(P<0.05)$. Serum $\mathrm{Zn}$ concentration differed significantly for I vs. I + Mix1 by D22 $(P<0.05)$ and D70 $(P<0.001)$ and for I vs. I + Mix2 by D70 $(P<0.001)$. Serum $\mathrm{Cu}$ concentration was influenced by time $(P<0.001)$ and differed significantly for I vs. I + Mix1 and I vs. I + Mix2 by D22 $(P<0.01)$.

\section{Effect on ovine feces microbial community}

Denaturing gradient gel electrophoresis (DGGE) was used to analyze changes in the fecal microbial communities of the infected lambs induced by supplementation with Mix1 and Mix2 (Fig. 2). A comparison of the DGGE banding patterns indicated that the communities were only weakly affected by supplementation with Mix1 and Mix2. Most of the samples had similar banding patterns, with similarity coefficients ranging from 0.20 to 0.58 . The cluster analyses (UPGMA) did not identify any herbal-mixture or animal-dependent clustering. None of the herbal treatments significantly affected the eubacterial microflora of the lambs infected with $H$. contortus.

\section{Discussion}

The use of medicinal herbs containing bioactive compounds with important biological activities for preventing and treating GIN infections has its origin in traditional herbal medicine. Phenolic acids and flavonoids were the main bioactive compounds identified in both Mix1 and Mix2, but Mix1 contained more of these compounds than Mix2. Phenolic acids and flavonoids mitigate diseases associated with oxidative stress [25] and had excellent antioxidant activity in both our in vitro and in vivo experiments. Their anthelmintic activities also provide a potential option for treating nematode infections [26]. The phenolic acids 1,5-dicaffeoylquinic and 3-O-caffeoylquinic identified in both Mix1 (15.37 and $11.31 \mathrm{mg} / \mathrm{g}$, respectively) and Mix2 (6.18 and $6.91 \mathrm{mg} / \mathrm{g}$, respectively) possess antibacterial and anthelmintic activities [27]. Rosmarinic acid has well-known anti-inflammatory and antioxidant biological activities with beneficial health-promoting effects [28]. Its contents in Mix1 was $5.95 \mathrm{mg} / \mathrm{g}$, two-fold higher than in a previously studied herbal mixture [23]. The presence of flavonol glycosides such as kaempferol, quercetin and myricetin contributes to the anthelmintic property of most browsed herbal species [29]. The herbal species in our study contained kaempferol $(0.3-9.0 \mathrm{mg} / \mathrm{g})$ and quercetin $(0.5-7.7 \mathrm{mg} / \mathrm{g})$, but the amount of myricetin was approximately three-fold higher in Mix1 than in another study [29]. Tannins and flavonoid glycosides may have similar mechanisms of action, because their chemical structures are similar [30]. All three groups of bioactive compounds also have antioxidant and anti-inflammatory properties [31, 32]. Another flavonoid with antioxidant activity, rutin, was also present in both Mix 1 (2.96 mg/g) and Mix2 $(5.73 \mathrm{mg} / \mathrm{g})$, within the range of $2.3-10 \mathrm{mg} / \mathrm{g}$ reported for other herbal extract [33]. The flavonoid luteolin, with antioxidant and anti-inflammatory properties [34], was 
Table 3 Contents of the main bioactive compounds identified in the Mix 1 analyzed in negative-ionization mode

\begin{tabular}{|c|c|c|c|c|c|c|c|c|}
\hline No. & Compound & RT (min) & UV & $m / z[M-H]^{-}$ & Formula & $\mathrm{MS}^{2}$ main ion & $\mathrm{MS}^{2}$ fragments & $\mathrm{mg} / \mathrm{g} \mathrm{DM}$ \\
\hline 1 & 4-O-Caffeoylquinic acid & 3.8 & $215 / 325$ & 353.0880 & $\mathrm{C}_{16} \mathrm{H}_{18} \mathrm{O}_{9}$ & 191.0553 & & 0.71 \\
\hline 2 & 3-O-Caffeoylquinic acid & 5.2 & $215 / 325$ & 353.0880 & $\mathrm{C}_{16} \mathrm{H}_{18} \mathrm{O}_{9}$ & 191.0556 & $179 / 161 / 135$ & 11.3 \\
\hline 3 & 5-O-Caffeoylquinic acid & 5.5 & $215 / 325$ & 353.0880 & $\mathrm{C}_{16} \mathrm{H}_{18} \mathrm{O}_{9}$ & 191.0557 & & 0.73 \\
\hline 4 & Caffeic acid & 6.9 & $215 / 324$ & 179.0339 & $\mathrm{C}_{9} \mathrm{H}_{8} \mathrm{O}_{4}$ & 135.0435 & & 0.81 \\
\hline 5 & 1-O-Feruloylglucose & 8.0 & $215 / 324$ & 355.1041 & $\mathrm{C}_{16} \mathrm{H}_{20} \mathrm{O}_{9}$ & 193.0498 & 149/0589/134 & 0.38 \\
\hline 6 & 3-O-p-Coumaroylquinic acid & 8.7 & $215 / 325$ & 337.0933 & $\mathrm{C}_{16} \mathrm{H}_{18} \mathrm{O}_{8}$ & 191.0187 & 173 & 0.65 \\
\hline 7 & 4-O-p-Coumaroylquinic acid & 9.5 & $215 / 325$ & 337.0933 & $\mathrm{C}_{16} \mathrm{H}_{18} \mathrm{O}_{8}$ & 191.0187 & 173 & 3.45 \\
\hline 8 & Caffeoylmalic acid & 9.7 & $313 / 000$ & 295.0455 & $\mathrm{C}_{13} \mathrm{H}_{12} \mathrm{O}_{8}$ & 179.0336 & $133 / 207$ & 1.42 \\
\hline 9 & 4-Caffeoylshikimic acid & 11.1 & $215 / 325$ & 335.0768 & $\mathrm{C}_{16} \mathrm{H}_{16} \mathrm{O}_{8}$ & 179.0334 & $161 / 191 / 135$ & 6.40 \\
\hline 10 & Glucodistylin & 11.5 & $218 / 295$ & 465.1024 & $\mathrm{C}_{21} \mathrm{H}_{22} \mathrm{O}_{12}$ & 285.0405 & $303 / 177$ & 4.90 \\
\hline 11 & Myricetin 3-O-galactosid & 12.2 & $271 / 345$ & 479.0828 & $\mathrm{C}_{21} \mathrm{H}_{20} \mathrm{O}_{13}$ & 317.0297 & & 20.2 \\
\hline 12 & Quercetin O-Pen-Hex & 12.3 & $252 / 351$ & 595.1298 & $\mathrm{C}_{26} \mathrm{H}_{28} \mathrm{O}_{16}$ & 300.0273 & & 2.63 \\
\hline 13 & Quercetin O-Hex-O-Dhex & 12.4 & $252 / 351$ & 609.1442 & $\mathrm{C}_{27} \mathrm{H}_{30} \mathrm{O}_{16}$ & 447.1131 & 152/429/161/179 & 0.96 \\
\hline 14 & Luteolin O-diglucuronide & 12.5 & $255 / 340$ & 637.1029 & $\mathrm{C}_{27} \mathrm{H}_{26} \mathrm{O}_{18}$ & 461.0707 & $285 / 04$ & 0.26 \\
\hline 15 & Rutin & 13.5 & $255 / 342$ & 609.1451 & $\mathrm{C}_{27} \mathrm{H}_{30} \mathrm{O}_{16}$ & 300.0275 & & 2.96 \\
\hline 16 & Acetoside (verbascoside) & 13.9 & 218/291/331 & 623.1972 & $\mathrm{C}_{29} \mathrm{H}_{36} \mathrm{O}_{15}$ & 461.1657 & 161/153/179/135 & 0.63 \\
\hline 17 & Quercetin O-Hex & 15.0 & $257 / 351$ & 463.0874 & $\mathrm{C}_{21} \mathrm{H}_{20} \mathrm{O}_{12}$ & 300.0273 & & 0.02 \\
\hline 18 & Quercetagetin 3'-methyl-ether 7-glucoside & 15.1 & $252 / 351$ & 493.0977 & $\mathrm{C}_{22} \mathrm{H}_{22} \mathrm{O}_{13}$ & 447.0928 & $331 / 285$ & 0.30 \\
\hline 19 & 3,5-Dicaffeoylquinic acid & 15.2 & $215 / 325$ & 515.1195 & $\mathrm{C}_{25} \mathrm{H}_{24} \mathrm{O}_{12}$ & 353.0877 & 173/179/335/191/161 & 0.42 \\
\hline 20 & Quercetin O-Pen & 15.3 & $252 / 351$ & 433.0776 & $\mathrm{C}_{20} \mathrm{H}_{18} \mathrm{O}_{11}$ & 300.0277 & $271 / 255 / 151$ & 1.41 \\
\hline 21 & 1,5-Dicaffeoylquinic acid & 15.4 & $215 / 325$ & 515.1194 & $\mathrm{C}_{25} \mathrm{H}_{24} \mathrm{O}_{12}$ & 353.0885 & 191/179/135 & 15.4 \\
\hline 22 & Qquercitrin & 15.4 & $256 / 348$ & 447.0904 & $\mathrm{C}_{21} \mathrm{H}_{20} \mathrm{O}_{11}$ & 300.0276 & & 1.88 \\
\hline 23 & Apigenin O-Hex & 15.5 & $267 / 341$ & 431.0983 & $\mathrm{C}_{21} \mathrm{H}_{20} \mathrm{O}_{10}$ & 268.0371 & & 0.33 \\
\hline 24 & Isorhamnetin O-Dhex-Dhex & 15.7 & $267 / 349$ & 607.1666 & $\mathrm{C}_{28} \mathrm{H}_{32} \mathrm{O}_{15}$ & 299.058 & 284 & 0.15 \\
\hline 25 & Quercetin O-(Hex-Ac) & 15.9 & $267 / 340$ & 505.0969 & $\mathrm{C}_{23} \mathrm{H}_{22} \mathrm{O}_{13}$ & 300.0727 & & 0.24 \\
\hline 26 & Rosmarinic acid & 16.1 & 218/287/329 & 359.0781 & $\mathrm{C}_{18} \mathrm{H}_{16} \mathrm{O}_{8}$ & 161.023 & 197/179 & 5.95 \\
\hline 27 & Kaempferol O-glucuronide & 27.2 & & 461.0727 & $\mathrm{C}_{21} \mathrm{H}_{18} \mathrm{O}_{12}$ & 285.0406 & 137 & 0.23 \\
\hline 28 & 3-Dihydrocaffeoyl-4-caffeoyl quinic acid & 16.4 & 215,325 & 517.1354 & $\mathrm{C}_{25} \mathrm{H}_{26} \mathrm{O}_{12}$ & 355.1239 & $161 / 179 / 323$ & 9.72 \\
\hline 29 & Kaempferol O-(Hex-Ac) & 16.8 & & 489.1036 & $\mathrm{C}_{23} \mathrm{H}_{22} \mathrm{O}_{12}$ & 284.0325 & $255 / 227 / 327$ & 0.72 \\
\hline 30 & Myricitrin glucuronide & 18.5 & & 519.1143 & $\mathrm{C}_{24} \mathrm{H}_{24} \mathrm{O}_{13}$ & 314.0435 & 269/243/357 & 0.76 \\
\hline 31 & Apigenin O-(Hex-Ac) & 18.8 & & 473.1093 & $\mathrm{C}_{23} \mathrm{H}_{22} \mathrm{O}_{11}$ & 268.0378 & & 0.73 \\
\hline 32 & Biochanin A-hexurunosyl-hexurunosyl & 19.5 & & 637.1774 & $\mathrm{C}_{29} \mathrm{H}_{34} \mathrm{O}_{16}$ & 283.0618 & & 0.65 \\
\hline 33 & Apigenin O-(Hex-Ac) & 20.1 & & 473.1095 & $\mathrm{C}_{23} \mathrm{H}_{22} \mathrm{O}_{11}$ & 268.0382 & & 1.57 \\
\hline
\end{tabular}

the most abundant compound in both Mix1 (Luteolin Odiglucuronide $-0.26 \mathrm{mg} / \mathrm{g}$, Table 3) and Mix2 (LuteolinO-Hex-Dhex - $1.43 \mathrm{mg} / \mathrm{g}$, Table 4). Luteolin and quercetin can inhibit the larval development $[35,36]$.

The ultra-high-resolution mass spectrometry (UHRMS) analysis of the bioactive compounds in Mix1 and Mix2 also identified protoberberine-type alkaloids. Alkaloids in herbal species are commonly poisonous [37], but protoberberine alkaloids have a large variety of biological and pharmacological [38] and anthelmintic [39, 40] activities. The anthelmintic activity of herbs has sometimes been ascribed to alkaloids, which can interfere with DNA synthesis in parasites [41]. Several examples indicated protoberberine type alkaloids as valuable substances with anti-parasitic activities. Among the alkaloids tested to find new anthelmintics against parasites living in host tissues, allocryptopine (protoberberine type alkaloid) showed significant nematocidal activity against the larvae of dog roundworm, Toxocara canis with low cytotoxicity, and was proposed as a potentially effective anthelmintic [42]. Fumaria indica closely related to Fumaria officinalis (presented in both Mix 1 and Mix2) is used as an anthelmintic in the traditional veterinary practices in Pakistan. The main alkaloids identified in this species responsible for 
Table 4 Contents of the main bioactive compounds identified in the Mix2 analyzed in negative-ionization mode

\begin{tabular}{|c|c|c|c|c|c|c|c|c|}
\hline No. & Compound & $\mathrm{RT}$ (min) & UV & $m / z[M-H]^{-}$ & Formula & $\mathrm{MS}^{2}$ main ion & $\mathrm{MS}^{2}$ fragments & $\mathrm{mg} / \mathrm{g} \mathrm{DM}$ \\
\hline 1 & 3-O-Caffeoylquinic acid & 4.7 & $215 / 325$ & 353.0880 & $\mathrm{C}_{16} \mathrm{H}_{18} \mathrm{O}_{9}$ & 191.0553 & $179 / 161 / 135$ & 6.91 \\
\hline 2 & 2-O-Caffeoylhydroxycitric acid & 5.2 & $215 / 324$ & 369.0464 & $\mathrm{C}_{15} \mathrm{H}_{14} \mathrm{O}_{11}$ & 189.003 & $127 / 207 / 179$ & 0.78 \\
\hline 3 & 1-O-Feruloylglucose & 5.7 & $215 / 324$ & 355.1046 & $\mathrm{C}_{16} \mathrm{H}_{20} \mathrm{O}_{9}$ & 193.0498 & $149 / 0589 / 134$ & 0.50 \\
\hline 4 & Caffeic acid & 6.1 & & 179.0342 & $\mathrm{C}_{9} \mathrm{H}_{8} \mathrm{O}_{4}$ & 135.0436 & & 1.09 \\
\hline 5 & Caffeoylmalic acid & 6.2 & $250 / 324$ & 295.046 & $\mathrm{C}_{13} \mathrm{H}_{12} \mathrm{O}_{8}$ & 179.0336 & $133 / 207$ & 1.27 \\
\hline 6 & 2-O-Feruloylhydroxycitric acid & 8.2 & $215 / 324$ & 383.0623 & $\mathrm{C}_{16} \mathrm{H}_{16} \mathrm{O}_{11}$ & 189.0039 & $191 / 337 / 127$ & 3.64 \\
\hline 7 & N-Malonyl-D-phenylalanine & 8.3 & & 250.0723 & $\mathrm{C}_{12} \mathrm{H}_{13} \mathrm{NO}_{5}$ & 165.055 & 207 & 1.88 \\
\hline 8 & Astilbin & 9.2 & & 449.1089 & $\mathrm{C}_{21} \mathrm{H}_{22} \mathrm{O}_{11}$ & 287.0561 & $259 / 243$ & 1.07 \\
\hline 9 & Nigellicine & 9.4 & & 245.0934 & $\mathrm{C}_{13} \mathrm{H}_{14} \mathrm{~N}_{2} \mathrm{O}_{3}$ & 203.0829 & & 0.69 \\
\hline 10 & Quercetin O-Pen-Hex & 10.1 & $255 / 352$ & 595.1298 & $\mathrm{C}_{26} \mathrm{H}_{28} \mathrm{O}_{16}$ & 300.0273 & & 0.48 \\
\hline 11 & Isoquercitrin O-Dhex & 10.2 & $252 / 351$ & 609.1459 & $\mathrm{C}_{27} \mathrm{H}_{30} \mathrm{O}_{16}$ & 300.0279 & & 0.54 \\
\hline 12 & Quercetin O-Hex & 10.5 & $252 / 351$ & 463.0874 & $\mathrm{C}_{21} \mathrm{H}_{20} \mathrm{O}_{12}$ & 301.0366 & $141 / 151$ & 2.25 \\
\hline 13 & Typhaneoside & 10.8 & $255 / 354$ & 769.2207 & $\mathrm{C}_{34} \mathrm{H}_{42} \mathrm{O}_{20}$ & 314.0436 & 595 & 2.71 \\
\hline 14 & Rutin & 11.0 & $255 / 352$ & 609.1451 & $\mathrm{C}_{27} \mathrm{H}_{30} \mathrm{O}_{16}$ & 300.0275 & & 5.73 \\
\hline 15 & 6-Hydroxykaempferol 7-glucoside isoquercitrin & 11.5 & $264 / 341$ & 463.089 & $\mathrm{C}_{21} \mathrm{H}_{20} \mathrm{O}_{12}$ & 300.0284 & & 1.64 \\
\hline 16 & Quercetin-O-glucuronide & 12.2 & $255 / 352$ & 477.0681 & $\mathrm{C}_{21} \mathrm{H}_{18} \mathrm{O}_{13}$ & 301.0359 & & 0.85 \\
\hline 17 & Kaempferol O-Hex & 12.3 & $265 / 343$ & 447.0937 & $\mathrm{C}_{21} \mathrm{H}_{20} \mathrm{O}_{11}$ & 285.0407 & & 1.0 \\
\hline 18 & Sorhamnetin 3-O-Dhex-Hex & 12.9 & & 623.1631 & $\mathrm{C}_{28} \mathrm{H}_{33} \mathrm{O}_{16}$ & 314.0436 & $461 / 161$ & 0.25 \\
\hline 19 & Patuletin O-Hex & 13.0 & $256 / 351$ & 493.099 & $\mathrm{C}_{22} \mathrm{H}_{22} \mathrm{O}_{13}$ & 331.0469 & $447 / 285 / 151$ & 0.41 \\
\hline 20 & 3,5-Dicaffeoylquinic acid & 13.2 & $215 / 325$ & 515.1208 & $\mathrm{C}_{25} \mathrm{H}_{24} \mathrm{O}_{12}$ & 353.0885 & $173 / 179 / 191$ & 0.92 \\
\hline 21 & Luteolin-O-Hex-Dhex & 13.9 & $265 / 343$ & 593.1518 & $\mathrm{C}_{27} \mathrm{H}_{30} \mathrm{O}_{15}$ & 285.0409 & & 1.43 \\
\hline 22 & Calendoflavoside & 14.1 & $351 / 000$ & 623.1627 & $\mathrm{C}_{28} \mathrm{H}_{33} \mathrm{O}_{16}$ & 315.0515 & 269 & 0.71 \\
\hline 23 & 3,4-Dicaffeoylquinic acid & 14.5 & $215 / 326$ & 515.1208 & $\mathrm{C}_{25} \mathrm{H}_{24} \mathrm{O}_{12}$ & 353.0885 & $173 / 179 / 191$ & 0.44 \\
\hline 24 & Apigenin O-Hex & 14.7 & $266 / 339$ & 431.0994 & $\mathrm{C}_{21} \mathrm{H}_{20} \mathrm{O}_{10}$ & 268.0382 & & 2.82 \\
\hline 25 & Isorhamnetin-O-Hex & 14.9 & $267 / 338$ & 447.0928 & $\mathrm{C}_{21} \mathrm{H}_{20} \mathrm{O}_{11}$ & 284.0332 & $300 / 0279 / 327 / 255$ & 1.11 \\
\hline 26 & 1,5-Dicaffeoylquinic acid & 15.2 & $214 / 325$ & 515.1206 & $\mathrm{C}_{25} \mathrm{H}_{24} \mathrm{O}_{12}$ & 353.0885 & $173 / 179 / 191$ & 6.18 \\
\hline 27 & Isorhamnetin O-(Hex-Ac) & 15.3 & $260 / 000$ & 519.1141 & $\mathrm{C}_{24} \mathrm{H}_{24} \mathrm{O}_{13}$ & 314.0436 & $331 / 299$ & 1.75 \\
\hline 28 & Quercetin O-(Hex-Ac) & 15.4 & $255 / 355$ & 505.0963 & $\mathrm{C}_{23} \mathrm{H}_{22} \mathrm{O}_{13}$ & 300.0275 & 271 & 0.25 \\
\hline 29 & 3-caffeoyl-4-dihydrocaffeoyl quinic acid & 15.9 & $215 / 325$ & 517.1358 & $\mathrm{C}_{25} \mathrm{H}_{26} \mathrm{O}_{12}$ & 323.0779 & 193/161/179/149/221 & 0.49 \\
\hline 30 & Apigenin O-(Hex-Ac) & 16.5 & $265 / 325$ & 473.1101 & $\mathrm{C}_{23} \mathrm{H}_{22} \mathrm{O}_{11}$ & 268.0385 & & 1.94 \\
\hline
\end{tabular}

those activities are protopine, fumarizine, papraine, papracine as well as flavonoids, glycosides, tannins and saponins [43]. In both herb mixtures was similar content of protoberberine-type alkaloids. Therefore it seems that better in vivo anthelmintic potential of Mix1 was probably mediated by content of phenolic acids and flavonoids. This is consistent with recent results reported limited anthelmintic potential of some alkaloids [44]. However, potent alkaloids probably act as antagonist of parasitic cholinergic receptors and lead to the development of novel drugs or may be used in combination with current anthelmintics to improve their efficacy [44].

The use of medicinal herbs containing bioactive compounds as an alternative treatment to chemical drugs is one approach that could reduce the development of resistance to antiparasitic drugs. One of our objectives was therefore to evaluate and compare the in vitro ovicidal and larvicidal efficacies of the aqueous and methanolic extracts of two herb mixtures against $H$. contortus. We previously evaluated the in vitro anthelmintic effects of aqueous and methanolic extracts from 13 species of medicinal herbs [45]. The results indicated that most herbs had a minimal effect on the hatching and larval development of $H$. contortus at the highest concentration used in the EHT and LDT. However, herbal extracts of four herbs (i.e., Artemisia absinthium, Matricaria chamomilla, Fumaria officinalis and Malva sylvestris) had strong anthelmintic activities in vitro [45]. We also previously showed that the wider spectrum of aqueous extracts from herbs (i.e., Althaea officinalis, A. 
Table $\mathbf{5}$ In vitro and in vivo anthelmintic activity against Haemonchus contortus

\begin{tabular}{|c|c|c|c|}
\hline Part A: In vitro & \multicolumn{3}{|c|}{ Concentration $(\mu \mathrm{g} / \mathrm{mL})$} \\
\hline Egg hatch test $\mathrm{ED}_{50} \pm \mathrm{SD}$ & Methanolic extract & \multicolumn{2}{|l|}{ Aqueous extract } \\
\hline Mix1 & $539.2 \pm 174.4$ & \multicolumn{2}{|l|}{$940.0 \pm 73.0^{* *}$} \\
\hline Mix2 & $486.9 \pm 228.9$ & \multicolumn{2}{|l|}{$880.0 \pm 67.8^{* *}$} \\
\hline \multicolumn{4}{|l|}{$\begin{array}{l}\text { Larval development } \\
\text { test } L D_{50} \pm S D\end{array}$} \\
\hline Mix1 & $266.6 \pm 107.2$ & \multicolumn{2}{|l|}{$922.7 \pm 232.1^{* *}$} \\
\hline Mix2 & $826.4 \pm 370.5$ & \multicolumn{2}{|l|}{$1256.5 \pm 465.0^{* *}$} \\
\hline Part B: In vivo & & \multicolumn{2}{|l|}{ Numbers of adult worms } \\
\hline \multirow[t]{2}{*}{$\begin{array}{l}\text { Mean number of adult } \\
\text { worms } \pm S D\end{array}$} & Infected animals & Infected animals with Mix1 & $\begin{array}{l}\text { Infected animals } \\
\text { with Mix2 }\end{array}$ \\
\hline & $1523 \pm 187$ & $1113 \pm 274^{*}$ & $1327 \pm 351$ \\
\hline
\end{tabular}

absinthium, M. chamomilla, F. officinalis and M. sylvestris) exhibited stronger ovicidal activity and larvicidal activity in comparison to methanolic extracts of herbs; however methanolic extract of $A$. absinthium was the most efficient in both EHT and LDT [45]. These results suggest that herbal mixtures should be enriched with herbs with the highest anthelmintic potencies. Previous in vitro studies [46, 47] have only addressed the effects of individual herbal extracts on $H$. contortus. Our study is the first to monitor the ovicidal and larvicidal effects of herbal mixtures. The relatively high values (i.e., weak effects of extracts) in our in vitro tests suggested that the herbal mixtures could have an indirect antiparasitic effect in vivo and may promote the resistance of the host to parasitic infection only in the longer term. The effects were significantly stronger for the methanolic than the aqueous extracts in both the in vitro tests, suggesting a higher potency of the methanolic extracts, in accordance with some previous studies $[48,49]$ when aqueous and methanolic extracts did not produce the same anthelmintic response.

The egg outputs of our three parasitized groups (I, I + Mix1 and I + Mix2) indicated that egg reduction was largest in the I+Mix1 lambs. Egg production by $H$. contortus females has been reported to remain high to D50 post-inoculation and then to decrease [50]. We found the same pattern, where mean EPGs peaked from D44 to D51. The rapid reduction in egg excretion in the treated groups after D44, however, may have been due to the beneficial effects of the herbal treatments, supported by the dissections where the number of adult $H$. contortus worms was significantly lower for I + Mix1. The chemical composition of both herbal mixtures had optimal nutritional value and digestibility. Some herbs in

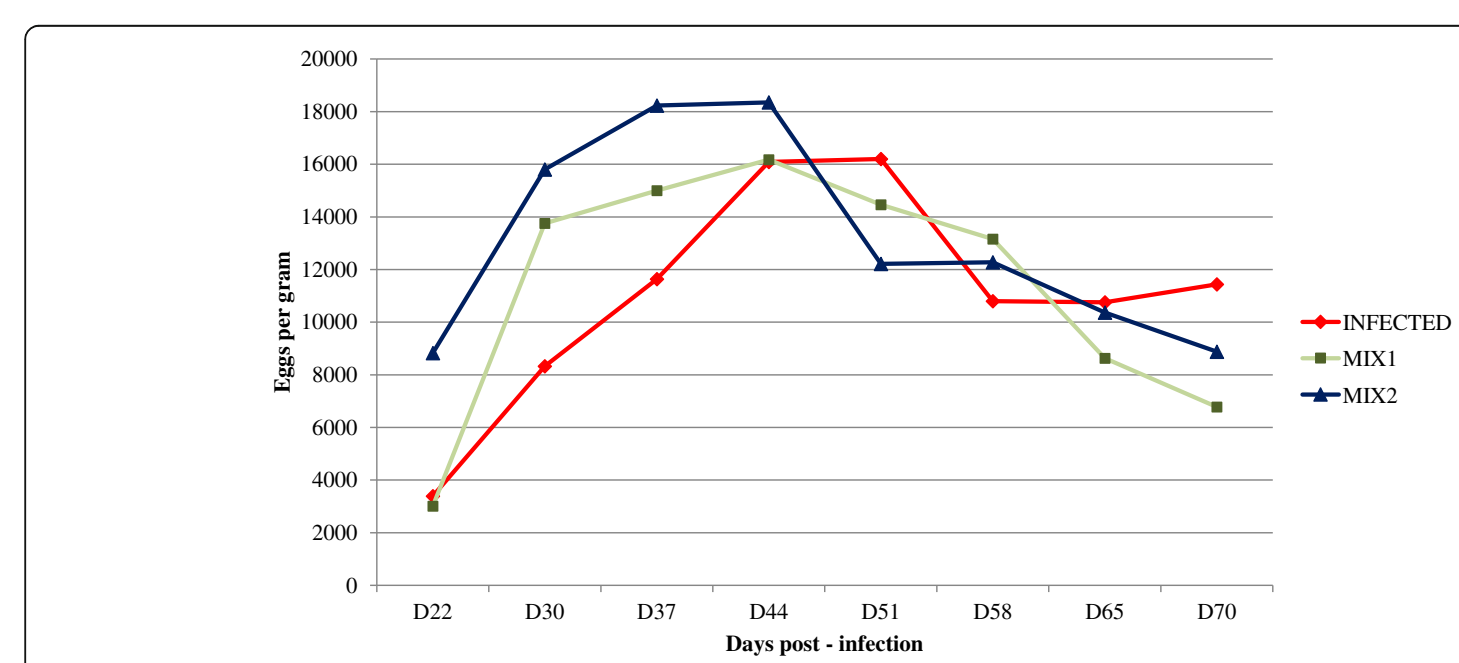

Fig. 1 Mean fecal egg counts for the groups of lambs infected with Haemonchus contortus 
Table 6 Inflammatory responses of the experimental lambs

\begin{tabular}{|c|c|c|c|c|c|c|c|c|c|c|c|}
\hline \multirow[t]{2}{*}{ Parameter } & \multirow[t]{2}{*}{ Day } & \multirow[t]{2}{*}{ C } & \multirow[t]{2}{*}{1} & \multirow[t]{2}{*}{$1+\operatorname{Mix} 1$} & \multirow[t]{2}{*}{$1+\operatorname{Mix} 2$} & \multirow[t]{2}{*}{ SD } & \multicolumn{5}{|c|}{ Significance of effect } \\
\hline & & & & & & & Treatment & | vs. $\mid+$ Mix 1 & | vs. I + Mix2 & Time & Treatment $\times$ time \\
\hline $\lg G$ & 22 & 0.073 & 0.321 & 0.544 & 0.525 & 0.0713 & $* *$ & $* *$ & * & NS & $* *$ \\
\hline \multirow[t]{3}{*}{$(\mathrm{mg} / \mathrm{mL})$} & 37 & 0.074 & 0.352 & 0.425 & 0.482 & 0.0858 & & NS & NS & & \\
\hline & 51 & 0.115 & 0.506 & 0.314 & 0.418 & 0.0931 & & $* *$ & NS & & \\
\hline & 70 & 0.091 & 0.484 & 0.244 & 0.351 & 0.0566 & & $* *$ & NS & & \\
\hline Calpro & 22 & 5.290 & 4.820 & 4.860 & 4.207 & 1.2650 & $* *$ & NS & NS & $* *$ & $* *$ \\
\hline \multirow[t]{3}{*}{$(\mathrm{ng} / \mathrm{mL})$} & 37 & 3.505 & 1.900 & 2.997 & 2.777 & 0.9263 & & NS & NS & & \\
\hline & 51 & 5.050 & 4.178 & 4.642 & 1.833 & 0.9462 & & NS & $* *$ & & \\
\hline & 70 & 3.665 & 4.877 & 5.882 & 2.178 & 1.3114 & & NS & $* *$ & & \\
\hline
\end{tabular}

$C$ control uninfected animals, I infected animals, I+Mix 1 infected animals with Mix1, I+Mix2 infected animals with Mix2, Calpro calprotectin, NS not significant ${ }^{*} P<0.01,{ }^{* *} P<0.001$

Mix2 have yet to be evaluated for their anthelmintic properties under experimental conditions. Our previous studies, however, found no adverse effects on the patterns of ruminal fermentation when the diet was substituted up to $10 \%$ by a mix of some of the medicinal herbs used in Mix1 and Mix2 [22, 51]. Mix1 and Mix2 did not significantly affect the body weights or liveweight gains of the infected lambs, in contrast to the previous results [22]. Meta-analysis reported significant negative effect of parasitism on production in $58.3 \%$ of the trials [52]. The level of IgG antibodies against $H$. contortus increased significantly after infection in each infected group. This activity was apparent throughout the experiment. The necropsy confirmed the significant reduction in worm burden in the group fed Mix1, which was probably due to an immune response in the infected lambs. Associations of serum IgG levels with GIN infection and resistance against GIN infection in sheep have been reported [53, 54]. The ability to resist GIN infection, however, depends on the development of a protective acquired immune response, although the level of immunity depends on age, nutritional status and host genotype [20]. Calprotectin is a non-specific serum marker of neutrophil activation that directly correlates with chemical mediators of intestinal inflammation and with macroscopic and microscopic signs of disease [55]. The serum levels of calprotectin in our study were influenced by the herbal treatments. The response of serum calprotectin, however, was inconsistent with previous results [22, 23]. Some infectious and inflammatory diseases increase the serum levels of calprotectin [56], but calprotectin is mainly an early biomarker of bacterial infections [57].

Infected lambs generally have a reduced ability to absorb nutrients from the gastrointestinal tract, leading to morbidity and occasional mortality. Our results

Table 7 Antioxidant status in the experimental lambs

\begin{tabular}{|c|c|c|c|c|c|c|c|c|c|c|c|}
\hline \multirow[t]{2}{*}{ Parameter } & \multirow[t]{2}{*}{ Day } & \multirow[t]{2}{*}{ C } & \multirow[t]{2}{*}{ I } & \multirow[t]{2}{*}{$1+\operatorname{Mix} 1$} & \multirow[t]{2}{*}{$1+\operatorname{Mix} 2$} & \multirow[t]{2}{*}{ SD } & \multicolumn{5}{|c|}{ Significance of effect } \\
\hline & & & & & & & Treatment & | vs. | + Mix 1 & | vs. I + Mix2 & Time & Treatment $\times$ time \\
\hline TAC & 22 & 0.552 & 0.537 & 0.538 & 0.543 & 0.055 & $* * *$ & NS & NS & NS & NS \\
\hline \multirow[t]{3}{*}{$(\mathrm{mmol} / \mathrm{L})$} & 37 & 0.593 & 0.508 & 0.562 & 0.568 & 0.060 & & NS & NS & & \\
\hline & 51 & 0.667 & 0.502 & 0.517 & 0.535 & 0.102 & & NS & NS & & \\
\hline & 70 & 0.560 & 0.458 & 0.550 & 0.548 & 0.075 & & NS & NS & & \\
\hline SOD & 22 & 2020 & 3139 & 2705 & 3048 & 731.9 & $* * *$ & NS & NS & * & NS \\
\hline \multirow[t]{3}{*}{ (U/g Hb) } & 37 & 2566 & 3572 & 3510 & 3768 & 1271 & & NS & NS & & \\
\hline & 51 & 2288 & 3592 & 3510 & 4206 & 1002 & & NS & NS & & \\
\hline & 70 & 2865 & 3859 & 3895 & 3764 & 974.4 & & NS & NS & & \\
\hline GPx & 22 & 0.114 & 0.109 & 0.108 & 0.101 & 0.038 & $* * *$ & NS & NS & $* * *$ & NS \\
\hline \multirow[t]{3}{*}{$(\mathrm{U} / \mathrm{mL})$} & 37 & 0.101 & 0.052 & 0.064 & 0.055 & 0.030 & & NS & NS & & \\
\hline & 51 & 0.091 & 0.075 & 0.051 & 0.053 & 0.022 & & NS & NS & & \\
\hline & 70 & 0.092 & 0.076 & 0.044 & 0.055 & 0.030 & & NS & NS & & \\
\hline
\end{tabular}

TAC total antioxidant capacity of serum, SOD superoxide dismutase activity in erythrocytes, GPx glutathione peroxidase activity in serum, $C$ control uninfected animals, $I$ infected animals, $I+$ Mix 1 infected animals with Mix1, I+Mix2 infected animals with Mix2, NS not significant ${ }^{*} P<0.05$, *** $P<0.001$ 
Table 8 Mineral status in the sera of the experimental lambs

\begin{tabular}{|c|c|c|c|c|c|c|c|c|c|c|c|}
\hline \multirow[t]{2}{*}{ Element } & \multirow[t]{2}{*}{ Day } & \multirow[t]{2}{*}{ C } & \multirow[t]{2}{*}{ I } & \multirow[t]{2}{*}{$1+\operatorname{Mix} 1$} & \multirow[t]{2}{*}{$1+\operatorname{Mix} 2$} & \multirow[t]{2}{*}{ SD } & \multicolumn{5}{|c|}{ Significance of effect } \\
\hline & & & & & & & Treatment & | vs. | + Mix1 & | vs. I + Mix2 & Time & Treatment $\times$ time \\
\hline \multirow[t]{4}{*}{$\mathrm{Zn}(\mathrm{mg} / \mathrm{L})$} & 22 & 0.476 & 0.462 & 0.567 & 0.591 & 0.07 & * & NS & NS & $* * *$ & NS \\
\hline & 37 & 0.548 & 0.477 & 0.512 & 0.519 & 0.03 & & NS & NS & & \\
\hline & 51 & 0.590 & 0.512 & 0.542 & 0.582 & 0.04 & & NS & NS & & \\
\hline & 70 & 0.687 & 0.590 & 0.548 & 0.682 & 0.07 & & NS & NS & & \\
\hline \multirow[t]{4}{*}{$\mathrm{Fe}(\mathrm{mg} / \mathrm{L})$} & 22 & 1.317 & 0.510 & 1.089 & 0.789 & 0.35 & $* * *$ & * & NS & $* * *$ & * \\
\hline & 37 & 1.575 & 0.724 & 0.975 & 0.935 & 0.37 & & NS & NS & & \\
\hline & 51 & 2.120 & 0.998 & 1.180 & 1.536 & 0.49 & & NS & NS & & \\
\hline & 70 & 2.188 & 0.618 & 1.665 & 1.585 & 0.66 & & $* * *$ & $* * *$ & & \\
\hline \multirow[t]{4}{*}{$\mathrm{Cu}(\mathrm{mg} / \mathrm{L})$} & 22 & 0.774 & 0.651 & 0.834 & 0.841 & 0.09 & NS & $* *$ & $* *$ & $* * *$ & NS \\
\hline & 37 & 0.773 & 0.696 & 0.724 & 0.732 & 0.03 & & NS & NS & & \\
\hline & 51 & 0.817 & 0.730 & 0.810 & 0.795 & 0.04 & & NS & NS & & \\
\hline & 70 & 0.835 & 0.876 & 0.810 & 0.873 & 0.03 & & NS & NS & & \\
\hline
\end{tabular}

$C$ control uninfected animals, $I$ infected animals, $I+$ Mix 1 infected animals with Mix $1, I+$ Mix 2 infected animals with Mix2, NS not significant

${ }^{*} P<0.05,{ }^{* *} P<0.01,{ }^{* * *} P<0.001$

indicated that nematode infection in lambs was associated with oxidative stress and affected the antioxidant status of the animals. Both herbal mixtures containing bioactive compounds had strong antioxidant properties but did not have a beneficial effect on the serum antioxidant parameters in the infected lambs. The antioxidant potential of the mixtures or their bioactive compounds may have been influenced by several factors in vivo, including gut absorption, metabolism, bioavailability and the presence or absence of co-antioxidants and ions of transition metals [25]. The significantly lower serum $\mathrm{Zn}$ and Fe levels of the infected lambs relative to the control suggest a disturbance in their metabolism caused by $H$. contortus. Both mixtures had high iron contents, so differences between unsupplemented infected lambs and infected lambs supplemented with a herbal mixture

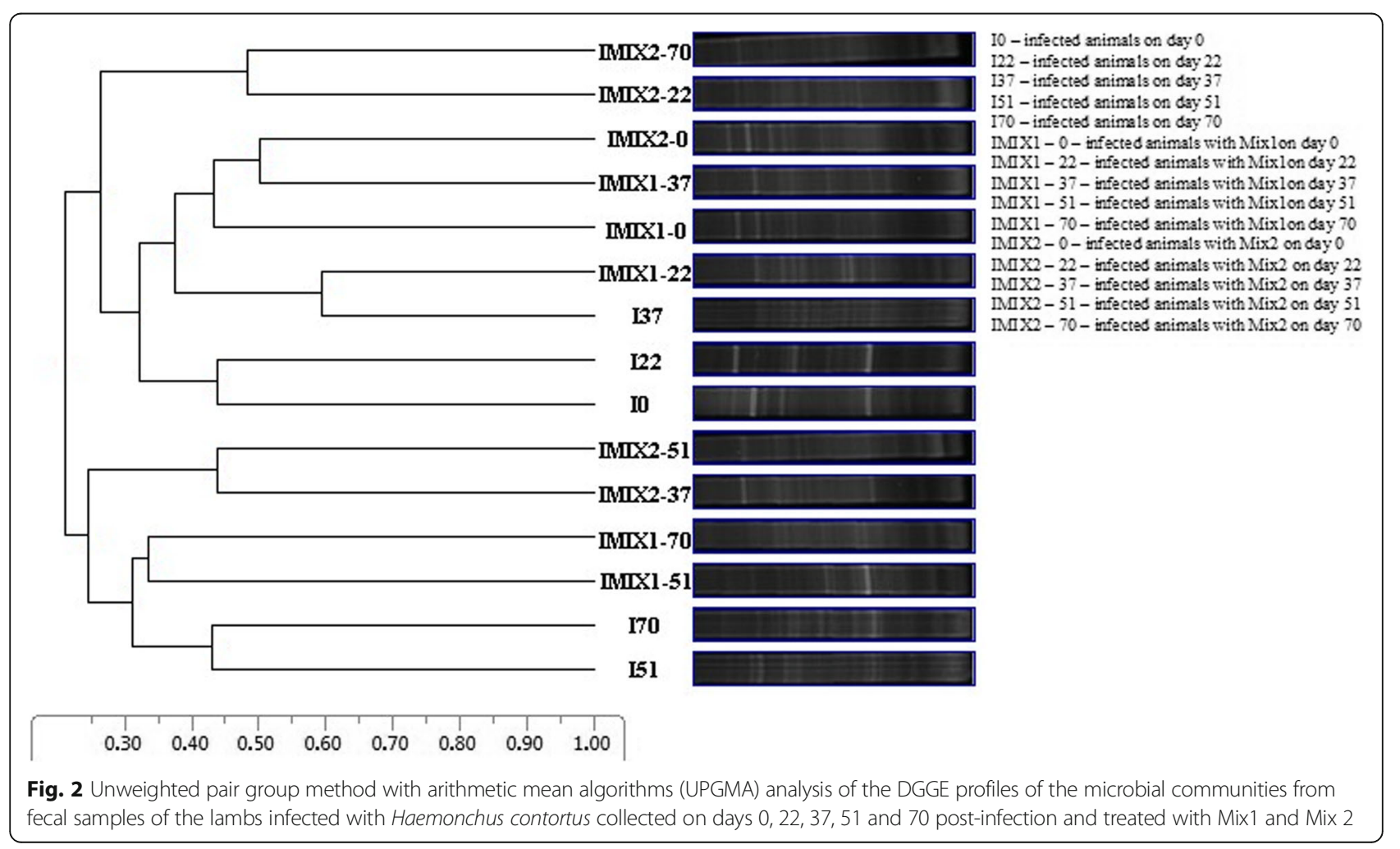


could influence the serum Fe status during treatment [58]. Some medicinal herbs from central Europe containing essential microelements have been reported to possess antioxidant capacity which is correlated with the content of total phenolic compounds [59].

Adding the herbal supplement to the diets of infected lambs did not affect the composition of the fecal eubacterial communities in a substrate-specific manner. Haemonchus contortus manipulates the ovine gastrointestinal microbiome, modifying the balance between host and gastric microbiota [60]. Denaturing gradient gel electrophoresis can evaluate just the most dominant members of the bacterial community accounting for at least $3 \%$ of total population. We can assume that the main constituents of fecal microbial community were not influenced by the treatments. The diversity of the gastrointestinal microbiome is also extremely high, and the microbiome of adult $H$. contortus worms and L3 larvae differ between abomasa and feces [61]. Finding supplements that influence parasites, bacteria and the host is therefore important for the long-term maintenance of sheep health.

\section{Conclusion}

The Mix1 had better in vivo anthelmintic potential than Mix2, probably due to its higher contents of phenolic acids and flavonoids. The in vitro results demonstrated an anthelmintic effect of the mixtures on $H$. contortus, but the in vivo experiments indicated that this effect was not sufficient for the primary elimination of parasites. Mix1, however, may affect the host over the longer term, leading to a reduction in parasitic infection intensity in the host. Multidisciplinary approach to control infection is important and provides a more complex view without overestimating partial results.

\section{Methods}

Experimental design, nutrition and animal management Animal use and experimental design were approved by the Ethics Committee of the Institute of Parasitology of the Slovak Academy of Sciences in accordance with the national legislation in Slovakia, Animal Welfare Act (No. 23/2009). Permission to collect samples and to carry out the experiment was granted by the participating sheep farmers. Twenty-four female lambs (Improved Valachian) 3-4 months of age with initial body weights of $11.7 \pm 1.23 \mathrm{~kg}$ were housed in common stalls for $15 \mathrm{~d}$ to acclimatize to the feeding treatments, with free access to water. The lambs were obtained from a commercial farm (Agricultural farm, Kluknava, Slovakia) and were maintained in their productive system during the experiment. All parasite-free lambs were then randomly divided on their live-weight into four groups (six lambs/group, one stall/group): uninfected control animals (C), animals infected with $H$. contortus (I), infected animals supplemented with herbal mixture 1 (I + Mix 1$)$ and infected animals supplemented with herbal mixture $2(\mathrm{I}+\mathrm{Mix} 2)$. The number of animals used in the experiment was assigned following VICH GL13 guidelines proposed by European Medicines Agency. Lambs were infected orally with approximately 5000 third-stage (L3) larvae of the MHcol strain of $H$. contortus, which is susceptible to all main classes of anthelmintics. The experimental period was 70 days (during summer), and the animals were housed on a sheep farm. Lambs were fed the Mix1 and Mix2 (100 g DM/d/animal) during the experimental period.

\section{Parasitological techniques}

Aqueous and methanolic extracts were prepared from both mixtures for EHTs and LDTs as was previously described [45]. Ovicidal activity was expressed as the concentration $(\mu \mathrm{g} / \mathrm{mL})$ of median effective dose $\left(\mathrm{ED}_{50}\right.$, the concentration of a methanolic or aqueous extract that prevented $50 \%$ of the eggs from hatching). Larvicidal activity was expressed as the concentration $(\mu \mathrm{g} /$ $\mathrm{mL})$ of median lethal dose $\left(\mathrm{LD}_{50}\right.$, the concentration of a methanolic or aqueous extract that prevented $50 \%$ of the larvae from developing to the infective L3 stage).

Fecal samples from lambs were collected on D0, D22, D30, D37, D44, D51, D58, D65 and D70 post-infection and stored at $5{ }^{\circ} \mathrm{C}$ until laboratory examination. The detection of strongylid eggs was performed as was previously described [62]. All animals were humanely killed on D70 (abattoir of the Centre of Biosciences of SAS, Institute of Animal Physiology, Košice, Slovakia, No. SK U 06018), and helminthological dissections were performed [23]. The carcasses of animals were sent at the Department of Pathological Anatomy and Pathological Physiology, University of Veterinary Medicine and Pharmacy in Košice in Slovak Republic.

\section{Chemical analysis and fermentation parameters of the dietary substrates}

The dietary substrates were analyzed in triplicate by standard procedures $[63,64]$. The chemical composition of the Mix1 and Mix2, respectively, was (mean values, g/ kg DM): DM: 898 (895); NDF: 500 (460); ADF: 360 (350): CP: 160 (180); N: 26 (29); ash: 110 (110); IVDMD: 600 (670); (mg/kg DM): Zn: 32.4 (36.7); Fe: 380 (396); $\mathrm{Cu}: 11.3$ (13.8). IVDMD and in vitro measurements (Table 2) followed the procedures [22]. Ciliated protists in the fermentation ruminal fluid were counted microscopically and identified [65].

\section{Analysis of bioactive compounds}

Phenolic acids and flavonoids in the samples of Mix1 and Mix2 were analysed as was previously described 
[23]. For the analysis of the protoberberine-type alkaloids, the Mix1 and Mix2 samples were ground to a fine powder, and $7 \mathrm{~g}$ of each were extracted with $0.5 \mathrm{M}$ $\mathrm{H}_{2} \mathrm{SO}_{4}$ in an ultrasonic bath at $25^{\circ} \mathrm{C}$ for $20 \mathrm{~min}$. This procedure was then repeated, and the filtrates were combined, adjusted to $\mathrm{pH} 9-10$ using $1 \mathrm{M} \mathrm{NaOH}$ and separated using $\mathrm{CHCl}_{3}$. The organic layer was collected, evaporated to dryness under reduced pressure and then dissolved in $80 \% \mathrm{MeOH}$ for further analysis. The bioactive compounds were analyzed by UHRMS on a Dionex UltiMate 3000RS system (Thermo Scientific, Darmstadt, Germany) with a charged aerosol detector connected to a high-resolution quadrupole time-of-flight mass spectrometer (Compact, Bruker Daltonik GmbH, Bremen, Germany) as was previously described [23]. The total content of protoberberine-type alkaloids was determined as a chelidonine (CAS 476-32-4) equivalent from calibration curves based on seven concentration points of chelidonine (from 200 to $1.2 \mu \mathrm{g} / \mathrm{mL}$ ). Alkaloids were separated using the same chromatographic conditions as for the phenolic compounds, except the gradient was from 7 to $70 \%$ phase B in phase A over $20 \mathrm{~min}$. All analyses were performed in triplicate.

\section{Antioxidant and mineral parameters}

Activity of blood glutathione peroxidase (GPx) and total antioxidant capacity (TAC) of the sera were determined as previously described [22, 23]. Superoxide dismutase (SOD) activity in erythrocytes was analyzed in fresh blood using a commercial kit (RANSOD, Randox Laboratories, Ltd., London, UK). Enzymatic activity was evaluated at $37{ }^{\circ} \mathrm{C}$ and a wavelength of $505 \mathrm{~nm}$ using an UV-VIS Spectrophotometer (UV-2550, Shimadzu Co., Kyoto, Japan) and the results are expressed in units/g hemoglobin. The serum mineral content was determined by flame atomic absorption spectrometry in an airacetylene flame, with deuterium background correction, using an AA-7000 atomic absorption spectrophotometer (Shimadzu Co., Kyoto, Japan) as was described [22, 23].

\section{Inflammatory response}

Haemonchus contortus antigen ( $\mathrm{HcAg}$ ) was obtained from ca. 50,000 L3. The larvae were washed twice in phosphate buffered saline (PBS, pH 7.4), diluted to a volume $15 \mathrm{~mL}$ and homogenized in an ice-cold glass (Sonopuls ultrasonic homogenizer HD3100, Bandelin, Germany). The homogenate was centrifuged (Heraeus Megafuge 16R, Thermo Fisher Scientific, Waltham, USA) at $4500 \mathrm{~g}$ for $5 \mathrm{~min}$ at $4{ }^{\circ} \mathrm{C}$, and the supernatant was concentrated in 3000 MWCO VIVASPIN tubes (Sartorius, Goettingen, Germany) at $4000 \mathrm{~g}$ for $100 \mathrm{~min}$ at $4{ }^{\circ} \mathrm{C}$. The protein concentration of the larval antigen was measured using the Bradford protein assay (Bio-Rad Laboratories, Munchen, Germany). Anti- $H$. contortus antibodies in the sera of the experimental lambs were detected using the HcAg somatic antigen and an indirect enzyme-linked immunosorbent assay (ELISA). Haemonchus contortus antigen was diluted to $5 \mu \mathrm{g} / \mathrm{mL}$ in carbonate buffer ( $\mathrm{pH}$ 9.6) and then bound to microtiter plates (Nunc, Thermo Fisher Scientific, Roskilde, Denmark) at $4{ }^{\circ} \mathrm{C}$ overnight. The wells were washed three times with $0.5 \%$ Tween 20 in PBS (pH 7.4, PBS-T), and non-specific bonds were blocked with PBS containing $0.5 \%$ skimmed milk after $1 \mathrm{~h}$ of incubation at room temperature. The wells were again washed three times with PBS-T, and the serum samples were diluted to 1 : 100 and incubated at $37^{\circ} \mathrm{C}$ for $1 \mathrm{~h}$. All samples were examined in duplicate. The wells were washed again as above and bound antibodies were detected by incubating at $37^{\circ} \mathrm{C}$ for $1 \mathrm{~h}$ with horseradish peroxidase-conjugated rabbit anti-sheep IgG (Sigma-Aldrich, Hamburg, Germany) diluted to $1: 10000$. The wells were washed again as above and $0.05 \mathrm{~mol} / \mathrm{l}$ of the substrate ophenylene diamine (Sigma-Aldrich, Hamburg, Germany) in citrate buffer $(\mathrm{pH} 4.7)$ with $0.005 \% \mathrm{H}_{2} \mathrm{O}_{2}$ was used to induce a color reaction. The reaction was stopped by 1 $\mathrm{M} \mathrm{H}_{2} \mathrm{SO}_{4}$ after a 15 -min incubation at room temperature in the dark. The optical density was measured at $492 \mathrm{~nm}$ (Multiskan Reader, Thermo Fisher Scientific, Vantaa, Finland). The concentration of serum calprotectin was determined using commercial sheep ELISA kits (MyBioSource, Inc., San Diego, USA).

\section{DNA isolation and PCR amplification}

Total DNA was extracted from frozen fecal samples using a QIAamp DNA Stool Mini Kit (Qiagen, Hilden, Germany). Isolated DNA was used as a template for the PCR amplification of 16S rRNA gene fragments. All PCRs were performed in $50-\mu \mathrm{L}$ volumes containing $1 \mu \mathrm{L}$ of DNA, $1 \times$ PCR buffer, $2 \mathrm{mmol} / \mathrm{L} \mathrm{MgCl}_{2}, 1 \mu \mathrm{L}$ of $200 \mu \mathrm{mol} / \mathrm{L}$ each dNTP, $1.25 \mathrm{U}$ of Platinum Taq DNA polymerase (Invitrogen, New York, USA) and $25 \mathrm{pmol}$ each primer using a $\mathrm{C} 1000^{\mathrm{m}}$ Thermal Cycler (Bio-Rad Laboratories, New York, USA). Universal primers fD1 (5'-AGA GTT TGA TCC TGG CTC AG-3') and rP2 (5'-ACG GCT ACC TTG TTA CGA CTT-3') [66] were used to amplify a 1500-bp region of the 16S rRNA gene in the first round of PCR. PCR conditions were: $94^{\circ} \mathrm{C}$ for $5 \mathrm{~min}$ and then $35 \mathrm{cycles}$ of $94^{\circ} \mathrm{C}$ for $1 \mathrm{~min}, 54^{\circ} \mathrm{C}$ for $1 \mathrm{~min}$ and $72{ }^{\circ} \mathrm{C}$ for $1 \mathrm{~min} 30 \mathrm{~s}$, followed by $72^{\circ} \mathrm{C}$ for 5 min. The 16S rRNA gene fragments were subsequently used as a template for the second round of PCR using the specific bacterial primers GC-clamp-968f ( $5^{\prime}$-CGC CCG GGG CGC GCC CCG GGC GGG GCG GGG GCA CGG GGG GAA CGC GAA GAA CCT TAC-3') and 1401r (5'-CGG TGT GTA CAA GAC CC-3') [67]. The cycling conditions were $94^{\circ} \mathrm{C}$ for $5 \mathrm{~min} ; 9$ cycles of $94{ }^{\circ} \mathrm{C}$ for $1 \mathrm{~min}, 45^{\circ} \mathrm{C}$ for $1 \mathrm{~min}$ and $72^{\circ} \mathrm{C}$ for $1 \mathrm{~min}$; 14 
cycles of $94{ }^{\circ} \mathrm{C}$ for $1 \mathrm{~min}, 60^{\circ} \mathrm{C}$ for $1 \mathrm{~min}$ and $72^{\circ} \mathrm{C}$ for 1 min and a final extension at $72{ }^{\circ} \mathrm{C}$ for $10 \mathrm{~min}$. The PCR products were detected by electrophoresis on a $0.8-1 \%$ agarose gel containing ethidium bromide and were photographed using a Gel Logic 212 PRO imaging system (Carestream, New York, USA). The second-round PCR products were subjected to DGGE. Denaturing gradient gel electrophoresis was performed using the DCodeTM Universal Mutation Detection System (BioRad Laboratories, Hercules, USA). The PCR products in a total volume of $45 \mu \mathrm{L}$ were loaded onto an $8 \%(\mathrm{w} / \mathrm{v})$ polyacrylamide gel (37.5:1 acrylamide:bis-acrylamide) in $1 \times \operatorname{TAE}(40 \mathrm{mM}$ Tris, $20 \mathrm{mM}$ acetate, $1 \mathrm{mM}$ EDTA) containing a linear denaturing gradient ranging from 30 to $60 \%$ denaturant (100\% denaturant solution consisted of $7 \mathrm{M}$ urea and $40 \%$ formamide). The electrophoresis was run for $17 \mathrm{~h}$ at a constant voltage of $51 \mathrm{~V}$ and a temperature of $60^{\circ} \mathrm{C}$. The gel was then incubated for 20 $\mathrm{min}$ in ethidium bromide $(0.5 \mu \mathrm{g} / \mathrm{mL})$, rinsed for $20 \mathrm{~min}$ in distilled water and photographed with UV transillumination using a Gel Logic 212 Pro Imaging System (Carestream, New York, USA).

\section{Calculations and statistical analysis}

Analyses of variance (ANOVAs) (GraphPad Prism, GraphPad Software, Inc., San Diego, USA) were used for analyzing the inflammatory responses, antioxidant and mineral statuses as repeated-measures mixed models representing the four animal groups $(\mathrm{C}, \mathrm{I}, \mathrm{I}+\mathrm{Mix} 1$ and I + Mix2) and sampling days. Effects included in the model were treatment, time and their interaction. Differences between the infected group (I) and both treated groups (I+ Mix1 and I + Mix2) were analyzed by a twoway ANOVA with a Bonferroni post hoc test. Student's $t$-tests were applied to assess the differences between the arithmetic EPG means on different sampling days from D44 for I, I + Mix1 and I + Mix2 and between worm counts at dissection. All EHT and LDT data were analyzed by Student's $t$-tests to assess the differences between the arithmetic means of $\mathrm{ED}_{50} / \mathrm{LD}_{50}$ for Mix 1 and Mix2 and between the aqueous and methanolic extracts. A probit model of regression analysis was applied to the data to express a median lethal dose $\left(\mathrm{ED}_{50}\right.$ and $\left.\mathrm{LD}_{50}\right)$. Differences were determined using Tukey's multiple comparison post hoc test. The significance level for all tests was set at $P<0.05$.

The gel images were processed using CLIQS 1D Pro software (Total Lab Ltd., Newcastle, UK). A dendrogram representing band-pattern similarities was constructed using the unweighted pair group method with arithmetic mean (UPGMA) algorithms. UPGMA uses a sequential clustering algorithm, in which local topological relationships are identified in order of similarity, and a phylogenetic tree is sequentially built.

\section{Abbreviations}

ADF: Acidic-detergent fiber; ANOVA: analysis of variance; C: control; Calpro: calprotectin; Concentrate: commercial concentrate composed of barley, soybean meal, wheat bran, bicarbonate and mineral-vitamin premix; CP: Crude-protein; D: day of sample collection; DGGE: denaturing gradient gel electrophoresis; DM: dry matter; DMSO: Dimethyl sulfoxide; EHT: egg hatch test; EPG: eggs per gram; GIN: gastrointestinal nematode; GPx: glutathione peroxidase; HcAg: Haemonchus contortus antigen; I + Mix 1: infected animals with herbal mixture $1 ; 1+$ Mix $:$ infected animals with herbal mixture 2; I: infected animals; IgG: immunoglobulin G; IVDMD: in vitro dry DM digestibility; LDT: larval development test; $\mathrm{MH}$ : meadow hay; $\mathrm{MS}^{2}$ : tandem mass spectrometry; N: nitrogen; NDF: neutral-detergent fiber; NS: not significant; SOD: superoxide dismutase activity in erythrocytes; TAC: total antioxidant capacity; UHRMS: ultra-high resolution mass spectrometry; UPGMA: unweighted pair group method with arithmetic mean algorithms

\section{Acknowledgements}

The authors are grateful to Valéria Venglovská, Renáta Geročová, Silvia Spišáková, Peter Jerga and Gabriel Benkovský for laboratory and technical assistance

\section{Authors' contributions}

DM performed the laboratory and statistical analyses and helped with wrote the manuscript. ZV interpreted the data and wrote the manuscript. AKop performed microbial community analyses. KC and LG reviewed the ethical application dossier and provided laboratory analysis. SK and AC helped with laboratory analyses and reviewed the manuscript. MB, MUD and AKon performed the in vivo and in vitro trials and the post-mortem examinations. ED conducted immunological analyses. JV assisted with in vitro experiments and reviewed the manuscript. SS provided analysis of the bioactive compounds in the herbal mixtures. MV designed the study protocol and supervised the research and reviewed the manuscript. All authors read and approved the final manuscript.

\section{Funding}

This study was supported by funds from the Slovak Research and Development Agency (APW 14-0169 and APW 18-0131). The role of APW projects allowed cooperation of researchers from Parasitological Institute of SAS and Institute of Animal Physiology of CBV of SAS. The funder had no role in study design, data collection and analysis, interpretation of data or writing of the manuscript.

\section{Availability of data and materials}

The data sets used and/or analyzed are available from the corresponding author on reasonable request.

\section{Ethics approval and consent to participate}

Animal use and study design were approved by the Ethics Committee of the Institute of Parasitology of the Slovak Academy of Sciences in accordance with the national legislation in Slovakia - Animal Welfare Act No. 23/2009. Permission to collect study samples was granted by participating sheep farmers. The owner of the animals gave verbal consent to carry out of the experiment.

\section{Consent for publication}

Not applicable.

\section{Competing interests}

The authors declare that they have no competing interests.

\section{Author details}

${ }^{1}$ Centre of Biosciences, Institute of Animal Physiology, Slovak Academy of Sciences, Košice, Slovak Republic. ${ }^{2}$ Institute of Parasitology, Slovak Academy of Sciences, Hlinkova 3, 04001 Košice, Slovak Republic. ${ }^{3}$ Department of Zoology and Fisheries, Czech University of Life Sciences Prague, Faculty of Agrobiology, Food and Natural Resources, Suchdol, Prague, Czech Republic. ${ }^{4}$ Department of Animal Nutrition, Poznan University of Life Sciences, Poznan, Poland. ${ }^{5}$ Department of Pharmaceutical Biology with Botanical Garden of Medicinal Plants, Medical University of Wroclaw, Wroclaw, Poland. 
Received: 22 May 2019 Accepted: 13 August 2019 Published online: 20 August 2019

\section{References}

1. Wolstenholme AJ, Fairweather I, Prichard R, von Samson-Himmelstjerna G, Sangster NC. Drug resistance in veterinary helminths. Trends Parasitol. 2004; 20:469-76.

2. Waghorn TS, Leathwick DM, Rhodes AP, Lawrence KE, Jackson R, Pomroy WE, West DM, Moffat JR. Prevalence of anthelmintic resistance on sheep farms in New Zealand. N Z Vet J. 2006;54:271-7.

3. Lamb J, Elliott T, Chambers M, Chick B. Broad spectrum anthelmintic resistance of Haemonchus contortus in northern NSW of Australia. Vet Parasitol. 2017;24:48-51.

4. Albuquerque ACA, Bassetto CC, Almeida FA, Amarante AFT. Development of Haemonchus contortus resistance in sheep under suppressive or targeted selective treatment with monepantel. Vet Parasitol. 2017;246:112-7.

5. Hoste H, Jackson F, Athanasiadou S, Thamsborg SM, Hoskin SO. The effects of tannin-rich plants on parasitic nematodes in ruminants. Trends Parasitol. 2006:22:253-61.

6. Hoste H, Torres-Acosta JFJ. Non chemical control of helminths in ruminants: adapting solutions for changing worms in a changing world. Vet Parasitol. 2011;180:144-54.

7. Hoste H, Torres-Acosta JF, Sandoval-Castro CA, Mueller-Harvey I, Sotiraki S, Louvandini H, Thamsborg SM, Terrill TH. Tannin containing legumes as a model for nutraceuticals against digestive parasites in livestock. Vet Parasitol. 2015;212:5-17.

8. Sandoval-Castro CA, Torres-Acosta JFJ, Hoste H, Salem AF, Chan-Pérez JI. Using plant bioactive materials to control gastrointestinal tract helminths in livestock. Anim Feed Sci Technol. 2012;176:192-201.

9. Viegi L, Pieroni A, Guarrera PM, Vangelisti R. A review of plants used in folk veterinary medicine in Italy as basis for a databank. J Ethnopharmacol. 2003; 89:221-44.

10. Lans C, Turner N, Khan T, Brauer G, Boepple W. Ethnoveterinary medicines used for ruminants in British Columbia. Canada J Ethnobiol Ethnomed. 2007:3:11.

11. Kabera JN, Semana E, Mussa AR, He X. Plant secondary metabolites: biosynthesis, classification, function and pharmacological properties. J Pharm Pharmacol. 2014;2:377-92.

12. Atanasov AG, Waltenberger B, Pferschy-Wenzig EM, Linder T, Wawrosch $C$, Uhrin P, Temml V, Wang L, Schwaiger S, Heiss EH, Rollinger JM, Schuster D, Breuss JM, Bochkov V, Mihovilovic MD, Kopp B, Bauer R, Dirsch VM, Stuppner H. Discovery and resupply of pharmacologically active plantderived natural products: a review. Biotechnol Adv. 2015;33:1582-614.

13. Lisonbee LD, Villalba JJ, Provenza FD, Hall JO. Tannins and self-medication: implications for sustainable parasite control in herbivores. Behav Process. 2009;82:184-9.

14. Villalba JJ, Miller J, Ungar ED, Landau SY, Glendinning J. Ruminant selfmedication against gastrointestinal nematodes: evidence, mechanism, and origins. Parasite. 2014;21:31

15. Athanasiadou S, Githiori J, Kyriazakis I. Medicinal plants for helminth parasite control: facts and fiction. Animal. 2007;1:1392-400.

16. Spiegler V, Liebau E, Hensel A. Medicinal plant extracts and plant-derived polyphenols with anthelmintic activity against intestinal nematodes. Nat Prod Rep. 2017;34:627-43.

17. Pandey AK, Mishra AK, Mishra A. Antifungal and antioxidative potential of oil and extracts derived from leaves of Indian spice plant Cinnamomum tamala. Cell Mol Biol. 2012;58:142-7

18. Kumar S, Pandey AK. Chemistry and biological activities of flavonoids: An overview. Sci World J. 2013;2013:162750.

19. Hoste H, Torres-Acosta JF, Quijada J, Chan-Perez I, Dakheel MM, Kommuru DS, Mueller-Harvey I, Terrill TH. Interactions between nutrition and infections with Haemonchus contortus and related gastrointestinal nematodes in small ruminants. Adv Parasitol. 2016;93:239-351.

20. McRae KM, Stear MJ, Good B, Keane OM. The host immune response to gastrointestinal nematode infection in sheep. Parasite Immunol. 2015;37:605-13.

21. Berrilli F, Di Cave D, Cavallero S, D'Amelio S. Interactions between parasites and microbial communities in the human gut. Front Cell Infect Microbiol. 2012;2:141.

22. Váradyová Z, Kišidayová S, Čobanová K, Grešáková L, Babják M, Königová A, Urda Dolinská M, Várady M. The impact of a mixture of medicinal herbs on ruminal fermentation, parasitological status and hematological parameters of the lambs experimentally infected with Haemonchus contortus. Small Rumin Res. 2017;151:124-32.

23. Váradyová Z, Mravčáková D, Babják M, Bryszak M, Grešáková L’, Čobanová K, Kišidayová S, Plachá I, Königová A, Cieslak A, Slusarczyk S, Pecio L, Kowalczyk M, Várady M. Effects of herbal nutraceuticals and/or zinc against Haemonchus contortus in lambs experimentally infected. BMC Vet Res. 2018;14:78.

24. Kresánek JJ, Kresánek J. Atlas of medicinal plants and berries. fourth ed. Slovakia: Osveta; 2008

25. Kasote DM, Katyare SS, Hegde MV, Bae H. Significance of antioxidant potential of plants and its relevance to therapeutic application. Int J Biol Sci. 2015;11:982-91.

26. Da Silva VC, De Carvalho MG, Borba HR, Silva SLC. Anthelmintic activity of flavonoids isolated from roots of Andira anthelmia (Leguminosae). Rev Bras Farm. 2008;18:573-6.

27. Xiong J, Li S, Wang W, Hong Y, Tang K, Luo Q. Screening and identification of the antibacterial bioactive compounds from Lonicera japonica Thunb. Leaves. Food Chem. 2013:138:327-33.

28. Borrás-Linares I, Stojanović Z, Quirantes-Piné R, Arráez-Román D, Švarc-Gajić J, Fernández-Gutiérrez A, Segura-Carretero A. Rosmarinus officinalis leaves as a natural source of bioactive compounds. Int J Mol Sci. 2014;15:20585-606.

29. Mengistu G, Hoste H, Karonen M, Salminen JP, Hendriks WH, Pellikaan WF. The in vitro anthelmintic properties of browse plant species against Haemonchus contortus is determined by the polyphenol content and composition. Vet Parasitol. 2017;237:110-6.

30. Barrau E, Fabre N, Fouraste I, Hoste H. Effect of bioactive compounds from sainfoin (Onobrychis viciifolia Scop.) on the in vitro larval migration of Haemonchus contortus: role of tannins and flavonol glycosides. Parasitology. 2005;131:531-8

31. Sultana B, Anwar F. Flavonols (Kaempeferol, quercetin, myricetin) contents of selected fruits, vegetables and medicinal plants. Food Chem. 2008;108: 879-84.

32. David AVD, Arulmoli R, Parasuraman S. Overviews of biological importance of quercetin: a bioactive flavonoid. Pharmacogn Rev. 2016;10:84-9.

33. Proestos C, Lytoudi K, Mavromelanidou OK, Zoumpoulakis P, Sinanoglou VJ. Antioxidant capacity of selected plant extracts and their essential oils. Antioxidants. 2013;2:11-22

34. Seelinger G, Merfort I, Schempp CM. Anti-oxidant, anti-inflammatory and anti-allergic activities of luteolin. Planta Med. 2008:74:1667-77.

35. Kozan E, Anul SA, Tatli II. In vitro anthelmintic effect of Vicia pannonica var. purpurascens on trichostrongylosis in sheep. Exp Parasitol. 2013;134:299-303.

36. Klongsiriwet C, Quijada J, Williams AR, Mueller-Harvey I, Williamson EM, Hoste $\mathrm{H}$. Synergistic inhibition of Haemonchus contortus exsheathment by flavonoid monomers and condensed tannins. Int J Parasitol Drugs Drug Resist. 2015:5:127-34.

37. Cortinovis C, Caloni F. Alkaloid-containing plants poisonous to cattle and horses in Europe. Toxins (Basel). 2015;7:5301-7.

38. Grycová L, Dostál J, Marek R. Quaternary protoberberine alkaloids. Phytochemistry. 2007;68:150-75.

39. Wang GX, Zhou Z, Jiang DX, Han J, Wang JF, Zhao LW, Li J. In vivo anthelmintic activity of five alkaloids from Macleaya microcarpa (maxim) Fedde against Dactylogyrus intermedius in Carassius auratus. Vet Parasitol. 2010;171:305-13.

40. Zenebe S, Feyera T, Assefa S. In vitro anthelmintic activity of crude extracts of aerial parts of Cissus quadrangularis $L$ and leaves of Schinus molle $L$ against Haemonchus contortus. Biomed Res Int. 2017;2017:1905987.

41. Magbool A, Hayat CS, Tanveer A. Comparative efficacy of various indigenous and allopathic drugs against fascioliasis in buffaloes. Vet Arch. 2004;74:107-14.

42. Satou T, Akao N, Matsuhashi R, Koike K, Fujita K, Nikaido T. Inhibitory effect of isoquinoline alkaloids on movement of second-stage larvae of Toxocara canis. Biol Pharm Bull. 2002;25:1651-4.

43. Al-Shaibani IRM, Phulan MS, Shiekh M. Anthelmintic activity of Fumaria parviflora (Fumariaceae) against gastrointestinal nematodes of sheep. Int J Agric Biol. 2009;11:431-6.

44. Dubois O, Allanic C, Charvet $\mathrm{CL}$, Guégnard F, Février H, Théry-Koné I, Cortet J, Koch C, Bouvier F, Fassier T, Marcon D, Magnin-Robert JB, Peineau N, Courtot E, Huau C, Meynadier A, Enguehard-Gueiffier C, Neveu C, Boudesocque-Delaye L, Sallé G. Lupin (Lupinus spp.) seeds exert anthelmintic activity associated with their alkaloid content. Sci Rep. 2019;9:9070.

45. Váradyová Z, Pisarčíková J, Babják M, Hodges A, Mravčáková D, Kišidayová S, Königová A, Vadlejch J, Várady M. Ovicidal and larvicidal activity of extracts 
from medicinal-plants against Haemonchus contortus. Exp Parasitol. 2018; 195:71-7.

46. Ahmed M, Laing MD, Nsahlai IV. In vitro anthelmintic activity of crude extracts of selected medicinal plants against Haemonchus contortus from sheep. J Helminthol. 2013:87:174-9.

47. Akkari H, Rtibi K, B'chir F, Rekik M, Darghouth MA, Gharbi M. In vitro evidence that the pastoral Artemisia campestris species exerts an anthelmintic effect on Haemonchus contortus from sheep. Vet Res Commun. 2014;38:249-55

48. Eguale T, Tilahun G, Debella A, Fleke A, Makonnen E. Haemonchus contortus: in vitro and in vivo anthelmintic activity of aqueous and hydro-alcoholic extracts of Hedera helix. Exp Parasitol. 2007;116:340-5.

49. Tariq KA, Chishti MZ, Ahmad F, Shawl AS. Anthelmintic activity of extracts of Artemisia absinthium against ovine nematodes. Vet Parasitol. 2009;160:83-8.

50. Borgsteede HM, Couwenberg T. Changes in LC50 in an in vitro egg development assay during the patent period of Haemonchus contortus in sheep. Res Vet Sci. 1987;42:413-4.

51. Váradyová Z, Mravčáková D, Holodová M, Grešáková L, Pisarčíková J, Barszcz M, Taciak M, Tuśnio A, Kišidayová S, Čobanová K. Modulation of ruminal and intestinal fermentation by medicinal plants and zinc from different sources. J Anim Physiol Anim Nutr (Berl). 2018;102:1131-45.

52. Mavrot $F$, Hertzberg $H$, Torgerson $P$. Effect of gastro-intestinal nematode infection on sheep performance: a systematic review and meta-analysis. Parasit Vectors. 2015;8:557.

53. Muñoz-Guzmán MA, Cuéllar-Ordaz JA, Valdivia-Anda AG, Buendía-Jiménez JA, Alba-Hurtado F. Correlation of parasitological and immunological parameters in sheep with high and low resistance to haemonchosis. Can J Anim Sci. 2006;86:363-71.

54. Cardia DF, Rocha-Oliveira RA, Tsunemi MH, Amarante AF. Immune response and performance of growing Santa Ines lambs to artificial Trichostrongylus colubriformis infections. Vet Parasitol. 2011;182:248-58.

55. Curry DB, Mizsputen SJ, Versolato C, Miiji LO, Pereira E, Delboni MA, Schor N, Moss AC. Serum calprotectin levels correlate with biochemical and histological markers of disease activity in TNBS colitis. Cell Immunol. 2013; 282:66-70.

56. Herrera OR, Christensen ML, Helms RA. Calprotectin: clinical applications in pediatrics. J Pediatr Pharmacol Ther. 2016;21:308-21.

57. Jonsson $N$, Nilsen T, Gille-Johnson P, Bell M, Martling CR, Larsson A, Mårtensson J. Calprotectin as an early biomarker of bacterial infections in critically ill patients: an exploratory cohort assessment. Crit Care Resusc. 2017;19:205-13.

58. Casanova VP, Aires AR, Collet SG, Krause A, Moresco RN, Bochi GV, Silva AS, Leal MLR. Iron supplementation for lambs experimentally infected by Haemonchus contortus: response to anemia and iron store in the bone marrow. Pesqui Vet Bras. 2018;38:1543-8.

59. Tupec M, Hýsková V, Bělonožníková K, Hraníček J, Červený V, Ryšlavá H. Characterization of some potential medicinal plants from Central Europe by their antioxidant capacity and the presence of metal elements. Food Biosci. 2017;20:43-50

60. El-Ashram S, Al Nasr I, Abouhajer F, El-Kemary M, Huang G, Dinçel G, Mehmood R, Hu M, Suo X. Microbial community and ovine host response varies with early and late stages of Haemonchus contortus infection. Vet Res Commun. 2017:41:263-77.

61. Sinnathamby G, Henderson G, Umair S, Janssen P, Bland R, Simpson H. The bacterial community associated with the sheep gastrointestinal nematode parasite Haemonchus contortus. PLoS One. 2018;13(2):e0192164.

62. Coles GC, Bauer C, Borgsteede FHM, Geerts S, Klei TR, Taylor MA, Waller PJ. World Association for the Advancement of Veterinary Parasitology (W.A.A.V. P) methods for the detection of anthelmintic resistance in nematodes of veterinary importance. Vet Parasitol. 1992;44:35-44.

63. Association of Official Analytical Chemists. Official methods of analysis. 17th ed. Arlington: AOAC; 2000.

64. Van Soest PJ, Robertson JB, Lewis BA. Methods for dietary fiber neutral detergent fiber, and non-starch polysaccharides in relation to animal nutrition. J Dairy Sci. 1991;74:3583-97.

65. Williams AG, Coleman GS. The rumen protozoa. New York: Springer-Verlag; 1992

66. Weisburg WG, Barns SM, Pelletier DA, Lane DJ. 16S ribosomal DNA amplification for phylogenetic study. J Bacteriol. 1991;173:697-703.

67. Nübel U, Engelen B, Felske A, Snaidr J, Wieshuber A, Amann RI. Sequence heterogeneities of genes encoding $16 \mathrm{~S}$ rRNAs in Paenibacillus polymyxa detected by temperature gradient gel electrophoresis. J Bacteriol. 1996;178:5636-43.

\section{Publisher's Note}

Springer Nature remains neutral with regard to jurisdictional claims in published maps and institutional affiliations.
Ready to submit your research? Choose BMC and benefit from:

- fast, convenient online submission

- thorough peer review by experienced researchers in your field

- rapid publication on acceptance

- support for research data, including large and complex data types

- gold Open Access which fosters wider collaboration and increased citations

- maximum visibility for your research: over $100 \mathrm{M}$ website views per year

At BMC, research is always in progress.

Learn more biomedcentral.com/submissions 